\title{
THE PROPOSAL OF MONITORING OF SLOW-WORM ANGUIS FRAGILIS L. AND EASTERN SLOW-WORM ANGUIS COLCHICA (NORDMANN, 1840) IN POLAND
}

Faculty of Animal Breeding, Bioengineering and Conservation, Warsaw University of Life Sciences, Warszawa, Poland

\begin{abstract}
The paper presents the proposal for monitoring methods of two species from Anguidae family occurring in Poland such as slow-worm $A$. fragilis and Eastern slow-worm $A$. c. incerta. Until recently, both species were considered to be the same taxon. Thanks to genetic research the Eastern slow-worm was isolated from the species $A$. fragilis. In recent years, phenotypic differences between $A$. fragilis and $A$. c. incerta have been described, but it has not been noticed whether there are any behavioral or habitat preference differences. Only the approximate boundary of the occurrence of both species in Poland is known. It may be important to distinguish common areas, as there are known cases of hybridization of $A$. c. incerta with $A$. fragilis in the Czech Republic and Hungary. Due to the recent isolation of the Eastern slow-worm, it is still not legally protected in Poland, unlike the partially protected slow-worm.
\end{abstract}

Key words: slow-worm, Eastern slow-worm, Anguidae, monitoring methods.

\section{INTRODUCTION}

The aim of this study is to propose the methods of monitoring the species from Anguidae family found in Poland.

\section{DESCRIPTION OF THE SPECIES}

Slow-worms are found in almost all of the Europe, from Great Britain and the central part of the Iberian Peninsula, east to the Urals and north to Scandinavia (up to $65^{\circ} \mathrm{N}$ of the parallel), and in south to the Apennine Peninsula and the Balkans. They are absent in Ireland, northern Scandinavia and some regions of southern Europe (Blab and Vogel 1996; Głowaciński and Sura 2018). Until recently, all European slow-worms were considered one species of $A$. fragilis L. with three subspecies (Głowaciński and Sura 2018). Currently, five species belong to the genus Anguis; A. cephallonica, A. veronensis, A. graeca, A. colchica and A. fragilis. In Poland, there are the last two, but in the case of Eastern slow-worm it is a subspecies of $A$. colchica incerta Krynicki, 1937 (Skórzewski 2017; Głowaciński and Sura 2018).

Corresponding author: Jakub Badziukiewicz, Faculty of Animal Breeding, Bioengineering and Conservation, Warsaw University of Life Sciences - SGGW, Józefa Ciszewskiego 8, 02-786 Warszawa, Poland, e-mail: jagubian1@gmail.com 
Slow-worm is a legless lizard with a cylindrical, elongated body, equally thick in the torso, covered with regular and tightly arranged smoothing scales with a characteristic glassy shine. Such a structure allows it to squeeze into loose soil, under various objects, crevices, moss, etc. Head unproportionally small, bluntly reachable, immediately cervical. The undamaged tail makes up the greater part of the body (on average 2-3 cm longer than the cephalothorax $53-55 \%$ of the body length), ends with a characteristic, hard, sharp and short callous spine. The slow-worm, like other domestic lizards, in threatening situations can throw off its tail, which then regenerates, but never to its original length (Juszczyk 1987; Młynarski 1991; Blab and Vogel 1996).

The body length of adults can reach up to $55 \mathrm{~cm}$ (Juszczyk 1987). As a rule, Eastern slow-worms are bigger, but it depends on whether the tested individual has an undamaged tail. Due to frequent shortcomings in its length, the current length is from the top of the head to the cloaca. These values in the case of $A$. fragilis, in males up to $215 \mathrm{~mm}$, in females up to $253 \mathrm{~mm}$, and the record-breaking male was $260 \mathrm{~mm}$ (Böhme 2012). Whereas in the case of $A$. colchica it varies in males $269 \mathrm{~mm}$ and in females $290 \mathrm{~mm}$ (Dely 1981; Głowaciński and Sura 2018).

According to Młynarski (1991), slow-worms have the remains of the pelvic and shoulder limbs inside their bodies.

On the head, slow-worms have five large scales: from the front, the largest - the frontal scale (sc. frontale), connects directly at the base with the triangular-shaped intertartar scale (sc. interparietale), the next two meet the sides of the previous one and are elongated - parietal scales (sc. parietalia), finally between them there is an occipital scale (sc. occipitale) (Juszczyk 1987).

One of the characteristic features by which we can distinguish species of slow-worms is the "pileus" type, i.e. the arrangement of prefrontal scales (sc. praefrontalia). There are three types, called types A, B and C. The first of these concerns A. fragilis whose prefrontal scales are in contact with the entire edge of the lateral wall, and the last type is in $A$. $c$. incerta whose scales do not touch at all (Fig. 1). In the B-type pileus, the prefrontal scales are in contact only with the vertices which may apply to both the eastern slow-worm and, less frequently, the slowworm, or their hybrids. There are also deviations in the arrangement of pileus scales or defects (Fig. 1) (Juszczyk 1987; Skórzewski 2017; Głowaciński and Sura 2018).

Both the body and stomach of the slow-worms are covered with scales of almost the same size. According to Juszczyk (1987), on the proximal edge of the cloaca, there are usually 6 anal scales, which are slightly larger than the other abdominal scales. The number of scales around the middle part of the body is also a feature that can be used to identify the species. In slow-worms it ranges from 24 to 26, while in Eastern slow-worms it is larger and occurs in the number of 26-30 scales (Juszczyk 1987; Skórzewski 2017; Głowaciński and Sura 2018).

The visible ear foramen is also of taxonomic importance only in A. colchica incerta.

In the case of $A$. fragilis, it is completely or partially covered by the scale, and therefore invisible or indistinct (Juszczyk 1987; Skórzewski 2017; Głowaciński and Sura 2018). As in the case of other domestic lizards, the eyes are framed by mobile, opaque lids covered with small scales. Teeth, in both the maxilla and the mandible, are pointed and clearly curved towards the tail, smaller in the front, and larger in the back, separated by gaps (Juszczyk 1987). 


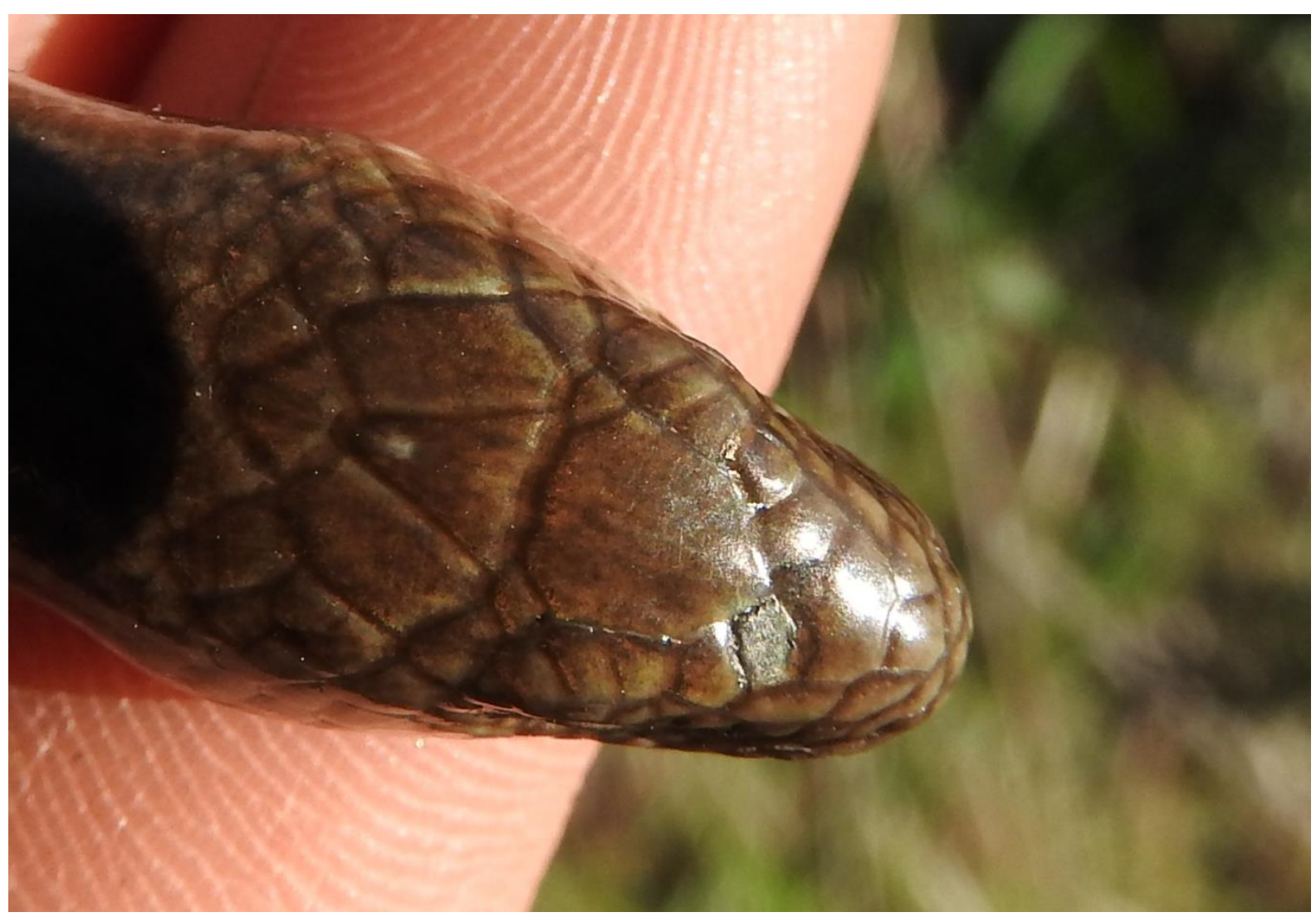

Fig. 1. Type $\mathrm{C}$ pileus with defect of scale visible in male Eastern slow-worm (photo J. Badziukiewicz)

The colour of slow-worms ranges from light to dark shades of brown, often with a characteristic copper sheen. They do not take mating colours. It is not uncommon to see dark broken or continuous lines on the back, especially in young animals, of various size and number. They run from the beginning of the trunk, along the length of the body, to the tip of the tail (Juszczyk 1987). Both slow-worms and Eastern slow-worms are characterized by a wide range of colours, of which the most interesting is the turquoise variety, which can also be used to mark the species. Well, in the case of $A$. fragilis, it occurs only in males, and in $A$. colchica incerta in both sexes, but more often in males (Skórzewski 2017; Głowaciński and Sura 2018). This variety is characterized by brown colour of the body without darker lines, while the dorsal part of the scales is greenish-blue with uneven spacing. They are most often found in the front part of the torso. The number of these scales is individual and is correlated not so much to gender as to age (Juszczyk 1987; Głowaciński and Sura 2018). The colour of the abdominal side is most often grey or shades of brown, less often black. Some individuals have a bluish underside of the body. Such a colour occurs in the case of $A$. fragilis only in females, and in $A$. colchica incerta in males, so it can also be used to determine the species of the tested individual (Juszczyk 1987; Głowaciński and Sura 2018).

It is difficult to determine the sex of slow-worms by phenotypic features. The dimorphism is rather invisible, except for the rarer colour variations mentioned above. According to Juszczyk (1987), the darker colour of the underside of the body is more common in females but it should not be considered a reliable way of distinguishing the sex of an individual. Adult males have 
larger, more expressive heads, which is crucial in copulation, while females have larger bodies, which is why they give birth to larger offspring (Głowaciński and Sura 2018). When examined and measured, males often extend their hemipenises (an even organ, partially inserted into the female's cloaca during copulation), which may also be helpful in distinguishing male from female (own observations).

\section{BIOLOGY OF THE SPECIES}

Slow-worms lead a secretive lifestyle. They are usually active at dusk and at night, also during the day after rain, when the temperature does not drop below $15^{\circ} \mathrm{C}$. They spend their days in burrows, wet brushwood or under objects that often quickly heat up. Pregnant females sometimes bask in the sun. They spend winter hibernating in haystacks (Fig. 2), in composts, buried in the soil even at the depth of $70 \mathrm{~cm}$, or in other places where the temperature does not drop significantly. It should be mentioned that they often hibernate in groups, even with other reptiles or amphibians. They become active in early spring depending on weather conditions when the nights get warmer and the days longer.

In autumn, they begin to hibernate (Juszczyk 1987; Głowaciński and Sura 2018; Klimaszewski 2019; Badziukiewicz 2021).

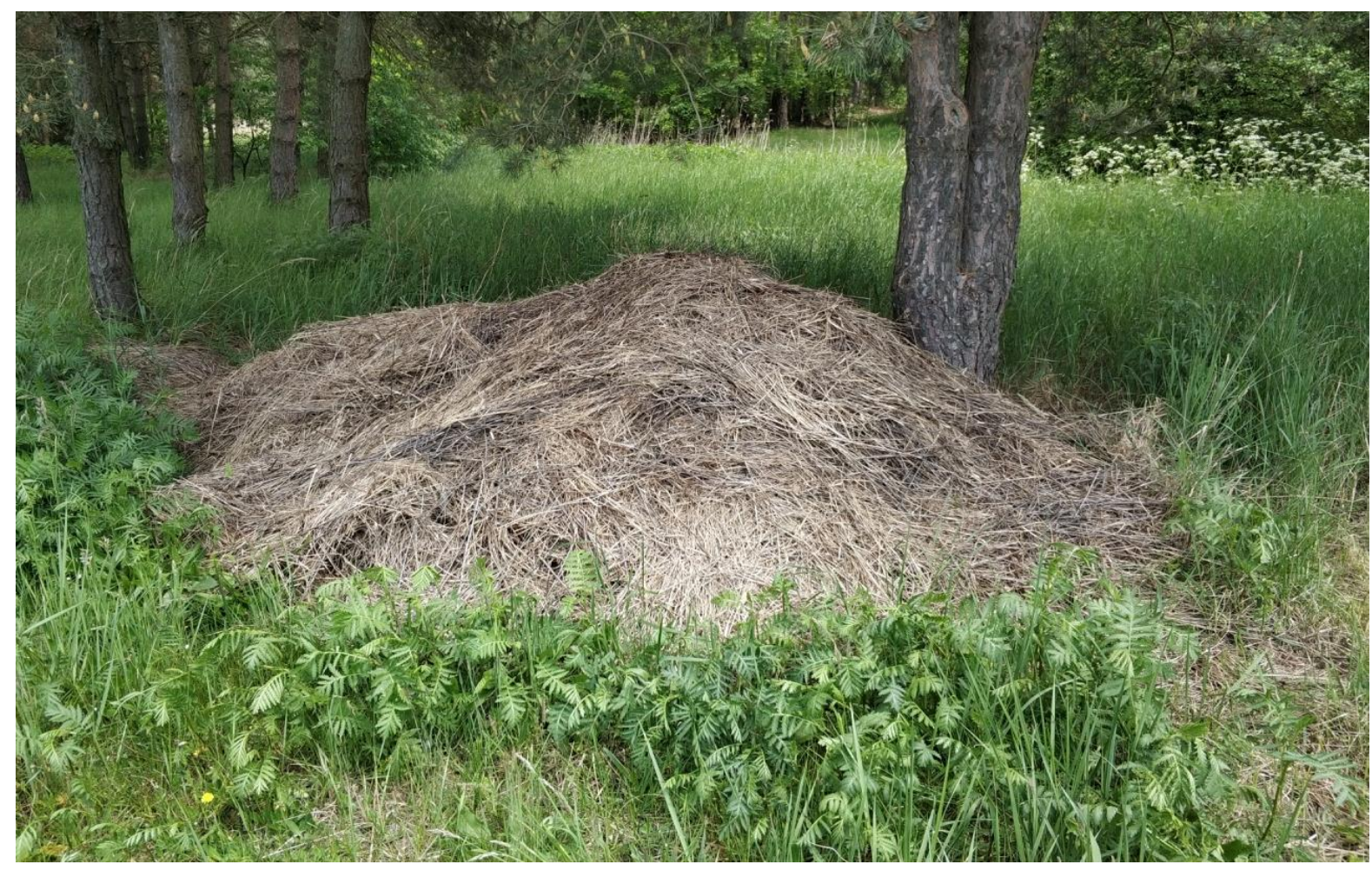

Fig. 2. A potential winter shelter of slow-worms (photo J. Badziukiewicz)

Slow-worms reach sexual maturity in the fourth year of life. The mating season is from April to June, and mating takes place covertly and resembles that of other lizards and can last for several hours. The male, when he meets the female ready for breeding, grabs her with 
his jaws and wraps around her body, then introduces one of the parts of the hemipenis into the female's cloaca. Moreover, it should be mentioned that males are fighting for dominance. Slow-worms are lecithotrophically viviparous animals, which means that the offspring develops in the female body. The young are born three months after mating (July-September). According to Juszczyk (1987), there are also numerous pregnant females in October, and sometimes even at the beginning of November. The numer of offsprings usually ranges from 6 to 12 juveniles, 6-10 cm long. Sometimes it is greater, reaching up to 16 individuals (Juszczyk 1987). Immediately after giving birth, the young are adapted to independent life. Slow-worms can live up to 15 years in the wild, and 20-28 years in captivity. The oldest record-breaking male lived for 54 years but the data is questionable (Juszczyk 1987; Głowaciński and Sura 2018; Klimaszewski 2019; Badziukiewicz 2021).

Slow-worms are rather inactive, slow and clumsy, so they often fall prey to predators. In emergency situations they can throw their tail back, just like other lizards. Sometimes they also damage it by squeezing into tight burrows or soil, hence, in the case of slow-worm Anguis fragilis, the Latin name "fragilis" means brittle. They mainly hunt snails and earthworms, but also other invertebrates. It should be mentioned that slow-worms can also swim perfectly. Like other lizards they lure several times a year but the difference is that they shed all their skin at once, just like snakes (Juszczyk 1987; Głowaciński and Sura 2018; Klimaszewski 2019).

\section{HABITAT REQUIREMENTS}

So far, the habitat requirements for both species of slow-worms found in Poland have not been distinguished and therefore it can be concluded that they are similar or identical. $A$. fragilis, and thus $A$. colchica, belong to the group of environmentally flexible reptiles (Blab and Vogel 1996) which means that they can be found both on xerothermic grasslands and in forests or near water reservoirs. However, they prefer areas with less sun exposure and a heterogeneous structure of vegetation, such as groves, mid-forest clearings, transparent forest areas - pine forests and hornbeam forests, also their edges and internal roads, where they often fall victim to collisions with cars or bicycles. The cover is often European blueberry, heather or other species of moss that provide shelter both from excessive sunlight and from predators. Due to their activity in the evening hours, slow-worms spend their sunny days under trees, stones or rubbish left by people. The moisture of the plating is also important. These animals are less frequently observed in arid areas, southern slopes or cultivated fields (Juszczyk 1987; Blab and Vogel 1996; Gierliński et al. 2015; Głowaciński and Sura 2018; Klimaszewski 2019; Badziukiewicz 2021).

The habitats of slow-worm and Eastern slow-worm in Poland may constitute the following habitat types from Annex I of the Habitats Directive:

- 9160 - Stellario-Carpinetum oak-hornbeam forest,

- 9170 - Galio-Carpinetum oak-hornbeam forests. 


\section{DISTRIBUTION OF THE SPECIES IN POLAND}

Slow-worms are found throughout Poland (Juszczyk 1987), $A$. fragilis in the northern, central and south-western parts, $A$. colchica incerta in the eastern and southern ones. The approximate boundary of the occurrence of both species runs from the south from the border with the Czech Republic, through the Opole region, Upper Silesia, Kielce region, Mazovia, up to Podlasie and Suwałki region to the border with Lithuania. At the moment, only two common refuges of slow-worm and Eastern slow-worm are known - the southern part of the Mazowiecki Landscape Park (own research 2021) and the Kozienice Landscape Park (unpublished research). The highest positions of slow-worms are located in the Babiogórski Range (1150 m) and Turbacz (1100 m), probably referring to A. c. incerta (Głowaciński and Sura 2018). In 2007, slow-worms were also observed in the Tatra Mountains at an altitude of $1700 \mathrm{~m}$, but these reports require professional confirmation (Głowaciński and Sura 2018).

\section{CONCEPT OF THE SPECIES MONITORING}

The presented concept of monitoring slow-worms in Poland was developed mainly on the basis of the publication: „Monitoring gatunków zwierząt. Przewodnik metodyczny. Część III. - Gniewosz plamisty Cornella austriaca austriaca Laurenti, 1768” (Najbar 2012), in which the author himself considered the work appropriate to a certain extent for research on the type of Anguis. The methodology was also prepared on the basis of the author's own experience and the specialist knowledge of the employees of the Institute of Animal Sciences of the Warsaw University of Life Sciences. The concept of monitoring slow-worm and Eastern slow-worm presented in this publication is only a proposal, and its refinement will be possible depending on the comments and reviews of specialists.

In the natural environment (in situ), field research is carried out, mainly consisting of searching for animals and procedures directly related to recording individual data. Field research should be conducted in accordance with the principles of herpetological inventory, therefore it is crucial to define the research area and transects. A grid dividing small research areas should be placed on the physical or computer map of the determined area. On each of them, observations are made and basic data on individuals, such as species, sex, estimated age, weight and body length is collected. In order to determine the species by phenotypic features, it is recommended to complete the documentation with data such as the type of pileus, the number of scales in the circumference of the middle part of the body, the visibility of the ear, the presence of turquoise scales on the back or the blue underside of the body. Determining the species on the basis of phenotypic characteristics is not always possible. In addition, the documentation should include the photos of the encountered specimen, their heads with a visible layout of the prefrontal scales and a profile with a clearly visible area around the ear, as well as special features allowing to distinguish the individual, such as a pattern of scars or missing lengths of the tail and scales. Due to the daily activity of slow-worms, it is recommended to conduct observations in the afternoon and evening hours 
in areas compatible with their habitat preferences. At other times of the day, in order to increase the likelihood of encountering individuals, the search should be made primarily under fallen trees, concrete slabs, rubbish, pieces of asbestos or other encountered objects. During the mating season, it is recommended to increase the frequency of exploration of the test area due to the increased activity of males. Due to their greater energy demand, pregnant females and adolescent individuals are easier to be encountered under lying objects that are quickly heated by the sun's rays. This also applies to other individuals on cooler days. Owing to the high mortality rate caused by road collisions, dead individuals should be expected mainly on roadways or roadsides.

Note: it should be mentioned that monitoring of slow-worms Anguis sp. is recommended, also "ex situ" - out of the natural environment. From the collected samples from dead and alive individuals, genetic tests are carried out to identify the individual. Due to the phenotypic similarity of the species of slow-worms, this type of research may help to determine how numerous a given species is in the study area, or to exclude the presence of one of them. Moreover, it should be examined whether the process of hybridation of slow-worm with Eastern slow-worm takes place in the areas of confirmed occurence of both species in Poland, Hungary and the Czech Republic (Szabó and Vörös 2014; Skórzewski 2017; Harca 2019).

\section{INDICATORS}

The habitat condition indicators are presented in Table 1. The method of valorization of population status and habitat indicators is presented in Table 2.

Table 1. Indicators of the state of population and habitat of slow-worm and Eastern slow-worm

\begin{tabular}{lll}
\hline Indicator & \multicolumn{1}{c}{ Measurement } & \multicolumn{1}{c}{ Means of measurement / determination } \\
\hline $\begin{array}{l}\text { Population } \\
\begin{array}{l}\text { The relative } \\
\text { size of the } \\
\text { population }\end{array}\end{array}$ & $\begin{array}{l}\text { number of } \\
\text { individuals }\end{array}$ & $\begin{array}{l}\text { Indicator defined as the number of lizards observed in the research area, } \\
\text { explored by the specimen method; the maximum number of individuals } \\
\text { observed during } 3 \text { counts }\end{array}$ \\
$\begin{array}{l}\text { The age } \\
\text { structure of } \\
\text { the } \\
\text { population }\end{array}$ & $\begin{array}{l}\text { The indicator is determined on the basis of careful observation and } \\
\text { exploration of the area as a percentage of young individuals, calculated as } \\
\text { the largest number of young individuals from } 3 \text { counts in relation to the } \\
\text { highest number of all young individuals from } 3 \text { counts; it was assumed that } \\
\text { individuals less than } 15 \mathrm{~cm} \text { in length can be considered young }\end{array}$
\end{tabular}

\begin{tabular}{|c|c|c|}
\hline \multicolumn{3}{|l|}{ Habitat } \\
\hline $\begin{array}{l}\text { The level of } \\
\text { shading }\end{array}$ & $\%$ & $\begin{array}{l}\text { The indicator is determined by the percentage of dense, tall vegetation } \\
\text { in the research area. }\end{array}$ \\
\hline $\begin{array}{l}\text { The } \\
\text { availability of } \\
\text { hiding places }\end{array}$ & $\begin{array}{l}\text { description } \\
\text { indicator }\end{array}$ & $\begin{array}{l}\text { Qualitative assessment of potential hiding places; an indicator determined } \\
\text { by an expert on a three-point scale (availability of hiding places - high, } \\
\text { medium, low) }\end{array}$ \\
\hline $\begin{array}{l}\text { Substrate } \\
\text { humidity }\end{array}$ & $\begin{array}{l}\text { description } \\
\text { indicator }\end{array}$ & $\begin{array}{l}\text { The indicator is determined by the presence of wetlands or areas with } \\
\text { increased substrate moisture within the reaserch area }\end{array}$ \\
\hline
\end{tabular}


Table 2. Valorization of slow-worm and eastern slow-worm population status and habitat indicators

\begin{tabular}{|c|c|c|c|}
\hline \multirow{2}{*}{ Indicator } & \multicolumn{3}{|c|}{ Evaluation } \\
\hline & FV & U1 & U2 \\
\hline \multicolumn{4}{|l|}{ Population } \\
\hline $\begin{array}{l}\text { The relative } \\
\text { size of the } \\
\text { population }\end{array}$ & $\begin{array}{l}\text { The same state as before or } \\
\text { an increase }\end{array}$ & $\begin{array}{l}\text { Compared to the previous } \\
\text { state, it decreased by one } \\
\text { point of the scale* }\end{array}$ & $\begin{array}{l}\text { Compared to the previous } \\
\text { state, it decrease by two or } \\
\text { more points*; or the first point } \\
\text { of the scale* }\end{array}$ \\
\hline $\begin{array}{l}\text { The age } \\
\text { structure of } \\
\text { the } \\
\text { population }\end{array}$ & $\begin{array}{l}\text { The share of young individuals } \\
\text { as before (unless it applies to } \\
\text { the first point of the scale }{ }^{\star *} \text { ) or } \\
\text { higher }\end{array}$ & $\begin{array}{l}\text { Compared to the previous } \\
\text { state, the share of young } \\
\text { individuals decreased by one } \\
\text { point of the scale }\end{array}$ & $\begin{array}{l}\text { Compared to the previous } \\
\text { state, the share of young } \\
\text { individuals decreased by two } \\
\text { scale points } \\
\text { of the scale }{ }^{* *}\end{array}$ \\
\hline \multicolumn{4}{|l|}{ Habitat } \\
\hline $\begin{array}{l}\text { The level of } \\
\text { shading }\end{array}$ & over $30 \%$ & $10-30 \%$ & under $10 \%$ \\
\hline $\begin{array}{l}\text { The } \\
\text { availability } \\
\text { of hiding } \\
\text { places }\end{array}$ & $\begin{array}{l}\text { High number of potential hiding } \\
\text { places. }\end{array}$ & $\begin{array}{l}\text { The average number of } \\
\text { potential hiding places. }\end{array}$ & $\begin{array}{l}\text { Small number of potential } \\
\text { hiding places. }\end{array}$ \\
\hline $\begin{array}{l}\text { Substrate } \\
\text { humidity }\end{array}$ & $\begin{array}{l}\text { At least one zone that con- } \\
\text { stantly maintains substrate } \\
\text { humidity or stagnant water } \\
\text { condition, with an area not ex- } \\
\text { ceeding } 50 \% \text { of the research } \\
\text { area; it can be a small body of } \\
\text { water, river / flowing water, } \\
\text { wet meadow, floodplain, wet } \\
\text { peat bog, swamp }\end{array}$ & $\begin{array}{l}\text { No constant access to } \\
\text { stagnant / flowing water, } \\
\text { areas where soil moisture } \\
\text { depends on the season; }\end{array}$ & $\begin{array}{l}\text { No zone with increased } \\
\text { substrate moisture / wetland; } \\
\text { the environment consists of } \\
\text { xerothermic or sandy grass- } \\
\text { lands, dry forests, mountain } \\
\text { slopes, dunes, or other areas } \\
\text { with dry ground, without } \\
\text { access to standing / flowing } \\
\text { water, swamps, wet peat } \\
\text { bogs, etc. }\end{array}$ \\
\hline
\end{tabular}

FV - good, U1 - unsatisfactory, U2 - bad.

* To evaluate the indicator, the relative size of the population, a five-point scale was established: $1^{\circ}-<10$ individuals; $2^{\circ}-11-30$ individuals; $3^{\circ}-31-50$ individuals; $4^{\circ}-51-100$ individuals; $5^{\circ}->100$ individuals. Relative population size is defined as bad when the size is at the first point of the scale.

${ }_{* \star}$ To evaluate the indicator, the age structure of the population (the share of young individuals to all those observed) was established on a four-level scale: $1^{\circ}-$ no young individuals; $2^{\circ}-<25 \%$ young individuals; $3^{\circ}-26-50 \%$ young individuals; $4^{\circ}->50 \%$ young individuals. The age structure of the population is bad when the abundance is on the first point of the scale.

Note: if a research area is monitored for the first time and it is impossible to relate the results of the observations to the previous data, the researcher must evaluate some indicators based on their specialist experience.

Cardinal indicators - not distinguished.

\section{PERSPECTIVE}

The conservation prospect assessment forecasts the state of the population and the state of the habitat in the next 10-15 years and is based on the expertise knowledge of the researcher. An important issue is the observation of environmental changes over the years, therefore the evaluation should be based on the history of the research area as well as the threats affecting the conservation status of biodiversity. The evaluation is made in the following categories: F1 - good prospects, population developing or maintaining a good level; U1 - not very favourable prospects, a slight decrease in the population or deterioration of the condition 
of the habitat, persisting unsatisfactory condition; U2 - bad prospects, population or habitat condition is likely to deteriorate significantly or remain in bad condition; XX - no data available to evaluate prospects.

\section{GENERAL EVALUATION}

The assessment of the lowest classified parameter (population, habitat, perspective) determines the general evaluation.

\section{THE METHOD OF PERFORMING THE RESEARCH}

\section{The choice of the monitored areas and their suggested size}

Research areas should be consistent with the habitat preferences of slow-worms and characterized by a large number of potential hiding places. The first criterion for selecting the research area should be habitats with the highest probability of occurrence of both slow-worm and Eastern slow-worm - the area within $50 \mathrm{~km}$ from the approximate boundary line of the occurrence of both species. Thanks to such information, it will be possible to determine the exact boundary of the occurrence of both domestic species of slow-worms. It should be mentioned that the literature data on the occurrence of Anguidae lizards in Poland is incomplete, therefore each research will help to broaden the knowledge on the recognition and distribution of these species.

The size of the research area depends on the researcher. It is recommended to limit the monitored habitat to an area of about 1 ha, then divide it into $10 \mathrm{~m} \times 10 \mathrm{~m}$ transects. A GPS transmitter should be used to determine the location and boundaries of the transects. Research documentation should also be completed with a map or sketch of the research area.

\section{Determination of population status indicators}

To determine the relative size of the population and its age structure, the observations should be made carefully by exploring the designated area. Due to the secretive lifestyle of slow-worms, it is recommended to control potential hiding places during the day, e.g. pick up all the objects encountered, such as trunks, fallen trees or litter left by people. At dusk and at night the area should be explored using a flashlight. The observations are also made on roadsides and forest roads due to the high mortality rate of slow-worms as a result of road collisions.

\section{The relative size of the population}

The indicator is determined by counting the individuals encountered during the monitoring research. Observations should be carried out both on a sunny day, looking under objects that can serve as a potential hiding place for slow-worms (e.g. tree fragments, pieces of furniture, car parts, stones, haystacks or compost, collected branches, façade and eternit fragments), and at dusk looking for active individuals with the help of a flashlight. It is recommended to conduct research in the morning $8.00 \mathrm{am}-10.00 \mathrm{am}$ and in the evening after 7:00 pm. While counting, exploration should be performed slowly, moving along designated $10 \mathrm{~m}^{2}$ transects. 
Potentially, artificial traps can also be used in the form of fragments of dark wooden boards (e.g. made of tar paper) or pieces of metal sheet, with dimensions of $0.5 \mathrm{~m} \times 0.5 \mathrm{~m}$, when there are no natural hiding places in the research area or access to them is difficult. It should be remembered that such activities require appropriate approvals and that the distributed traps must be properly marked. Individuals are counted three times during the active period of slow-worms activity. In order to prepare the documentation, each individual should be described separately, taking into account the appropriate measurements and photos taken. The relative size of the population is determined by the highest number of all encountered individuals (alive and dead) out of the three counts.

\section{The age structure of the population}

Slow-worms reach sexual maturity in the fourth year of life. It was assumed that young specimens do not exceed $15 \mathrm{~cm}$ in body length. The discussed index allows to assess the percentage of young individuals in relation to all identified individuals. In the monitored habitat slow-worms are counted three times in order to indicate whether a given population is developing, stabilized or dying out. The indicator is the largest share of young individuals in relation to all identified individuals from three counts.

\section{Determination of habitat indicators}

Three indicators were adopted: the level of shading, the availability of hiding places and substrate humidity. The first of them is determined by the percentage of the shade level, the second one is subject to individual assessment by the researcher, and finally the third indicator should be precisely described in accordance with historical data on environmental changes.

\section{The level of shading}

This indicator is directly related to the occurrence of forest formations. Although slow-worms are considered environmentally flexible reptiles, they prefer forest areas or areas with a significant level of tree cover. They are rarely observed in areas far away from forest clusters or with significant sun exposure, therefore such habitats should be the subject to unsatisfactory assessment.

\section{The availability of hiding places}

Due to their secretive lifestyle, slow-worms spend their days in hiding places, which is why their control is one of the main indicators of the habitat assessment. In the first place, it is recommended to search for them by picking up all the items that can be used as a hiding place.

\section{Substrate humidity}

The research area selected in accordance with the habitat preferences of slow-worms should be characterized by an appropriate level of moisture. These lizards are rarely observed in dry grasslands of a typical xerothermic nature. Therefore, such areas should be avoided. In a situation where the area is getting wet seasonally, the research should be carried out after periods of excessive moisture in the substrate. The presence of a high level of groundwater or water bodies has a positive effect on soil moisture, and thus increases the chances 
of slow-worm inhabiting the area. Each habitat on which monitoring are researched should be photographed (wet zone, degree of shading, characteristic vegetation, presence of hiding places), and the photos should be included in the documentation, thanks to which the changes in the ecosystem structure will be noticeable.

\section{TIME AND FREQUENCY OF RESEARCH}

Observations should be made during the activity of slow-worms, e.g. from early spring to autumn, depending on weather conditions and temperature. It is recommended to control the research area at intervals of 2-3 days. There is no fixed time for monitoring research. However, they should be carried out in at least three different months of the year. It is also recommended to explore the habitats immediately after the periods of increased rainfall. Monitoring studies are best carried out annually in order to obtain the information about changes in the population.

\section{THE SPECIES OF SIMILAR ECOLOGICAL REQUIREMENTS FOR WHICH THE DEVELOPED MONITORING METHODOLOGY OF ANGUIDAE FAMILY CAN BE ADAPTED}

Slow-worm A. fragilis, and thus Eastern slow-worm A. c. incerta, are environmentally flexible reptiles (Blab and Vogel 1996), therefore the developed methodology of monitoring activities can also be partially applied to other reptiles belonging to this group. These are the European adder $V$. berus and the viviparous lizard $Z$. vivipara.

\section{PROTECTION STATUS}

Currently, in Poland, only slow-worm A. fragilis is under partial species protection (DzU 2016, poz. 2183, zał. 2), while the Eastern slow-worm A. c. incerta not yet. The reason of the case is the not-so-old taxonomic separation. So far, no differences in habitat preferences or the biology of the two species have been demonstrated. Therefore, A. c. incerta is proposed to be partially protected. At present, no procedures related to the active protection of the genus Anguis are applied, moreover it is also not considered to be endangered in Poland.

\section{REFERENCES}

Badziukiewicz J. 2021. Habitat preferences of reptiles in Osieck region.

Blab J., Vogel H. 1996. Amphibien und Reptilien erkennen und schützen. München, BLV Verlagsgesellschaft $\mathrm{mbH}$.

Böhme W. 2012. A record-sized specimen of the western slow worm (Anguis fragilis). Z. Feldherpetol. 19, $117-118$.

Dely O.G. 1981. Anguis fragilis Linnaeus 1758 - Blindschleiche, in: Handbuch der Reptilien und Amphibien Europas, Band 1, Echsen I, ed. W. Böhme. Wiesbaden, Akademische Varlagsgesellschaft, 241-258.

Gierliński G., Grabowska J., Grabowski M., Jaskuła R. 2015. Ilustrowana encyklopedia płazów i gadów Polski. Bełchatów, Wydaw. Fenix. [in Polish]

Głowaciński Z., Sura P. 2018. Atlas płazów i gadów Polski: Status, rozmieszczenie, ochrona z kluczami do oznaczania. Warszawa, Wydaw. Nauk. PWN. [in Polish] 
Harca Z. 2019. Rozšíření slepýše křehkého (Anguis fragilis) a slepýše východního (Anguis colchica) na Moravě a ve Slezsku. Brno, Masarikova Univerzita, 2019.

Juszczyk W. 1987. Płazy i gady krajowe. Część 3. Gady. Warszawa, PWN. [in Polish]

Klimaszewski K. 2019. Fauna Polski. Płazy i gady. Warszawa, Oficyna Wydaw. Multico. [in Polish]

Młynarski M. 1991. Płazy i gady Polski. Warszawa, WSiP. [in Polish]

Najbar B. 2012. Gniewosz plamisty Coronella austriaca austriaca Laurenti, 1768, in: Monitoring gatunków zwierząt. Przewodnik metodyczny. Część III. GIOŚ, ed. M. Makomaska-Juchiewicz, P. Baran. Warszawa, Biblioteka Monitoringu Środowiska, 516-539. [in Polish]

Skórzewski G. 2017. Remarks on the studies and occurrence of the Eastern Slow Worm Anguis colchica incerta in Poland. Chrońmy Przyr. Ojcz. 73, 57-63.

Szabó K., Vörös J. 2014. Distribution and hybridization of Anguis fragilis and A. colchica in Hungary. Amphibia-Reptilia 35, 135-140.

\title{
PROPOZYCJA MONITORINGU PADALCA ZWYCZAJNEGO ANGUIS FRAGILIS L. ORAZ PADALCA KOLCHIDZKIEGO ANGUIS COLCHICA (NORDMANN, 1840) NA TERENIE POLSKI
}

\begin{abstract}
Streszczenie. W pracy przedstawiono propozycje metod monitoringu dwóch gatunków z rodziny Anguidae występujących w Polsce, takich jak padalec zwyczajny $A$. fragilis oraz padalec kolchidzki $A$. c. incerta. Oba gatunki do niedawna uznawane były za ten sam takson. Padalec kolchidzki został wyodrębniony z gatunku $A$. fragilis dzięki badaniom genetycznym. W ostatnich latach opisano różnice fenotypowe pomiędzy $A$. fragilis oraz $A$. c. incerta, lecz nie zauważono, czy występuja jakiekolwiek różnice behawioralne lub np. preferencji siedliskowych. Znana jest jedynie przybliżona granica występowania obu gatunków w Polsce. Istotne może być wyróżnienie obszarów wspólnych, ponieważ znane są przypadki hybrydyzacji $A$. c. incerta z $A$. fragilis w Czechach i na Węgrzech. Z uwagi na niedawne wyodrębnienie padalca kolchidzkiego w dalszym ciągu nie jest on chroniony prawnie na terenie Polski w odróżnieniu od częściowo chronionego padalca zwyczajnego.
\end{abstract}

Słowa kluczowe: padalec zwyczajny, padalec kolchidzki, Anguidae, metody monitoringu. 